\title{
TEKNIK PENGENDALIAN SERANGGA HAMA WALANG SANGIT (Leptocorisa oratorius) MELALUI PENYEMPROTAN LARUTAN BEUVERIA BASSIANA UNTUK TANAMAN PADI
}

\section{RICE EAR BUGS (Leptocorisa oratorius) CONTROL TECHNIQUE USING BEUVERIA BASSIANA LIQUID SPRAYING FOR RICE PLANTS}

\author{
Mareli Telaumbanua ${ }^{1 凶}$, Ristanti ${ }^{1}$, Elhamida Rezkia Amien ${ }^{1}$, Agus Haryanto $^{1}$, Winda \\ Rahmawati $^{1}$ \\ ${ }^{1}$ Jurusan Teknik Pertanian, Fakultas Pertanian,Uniersitas Lampung \\ ${ }^{\otimes}$ Komunikasi Penulis, email: mareli.telaumbanua@fp.unila.ac.id atau marelitelaumbanua@gmail.com \\ DOI:http://dx.doi.org/10.23960/jtep-lv9i4.374-382
}

Naskah ini diterima pada 5 Desember 2020; revisi pada 18 Desember 2020; disetujui untuk dipublikasikan pada 21 Desember 2020

\begin{abstract}
Rice ear bug is one of the factors causing rice growth failure. This research aims to increase the rice ear bug's mortality number using extract liquid from a biological agent Beuveria bassiana at various concentration levels. Beauveria bassiana liquid sprayed on rice ear bugs in a net type hood on rice plant clumps. The dosage of beuveria bassiana extracts mixed into the water at ratios in $2 \mathrm{ml} / \mathrm{L}, 5 \mathrm{ml} / \mathrm{L}, 8 \mathrm{ml} / \mathrm{L}$, and $10 \mathrm{ml} / \mathrm{L}$. The result shows that the best-used dosage in controlling the bug is $10 \mathrm{ml}$ of Beuveria bassiana extract liquid in 1 liter of water. It is shown from the percentage of rice ear bug's mortality, which is the highest (76.92\%) for 12 days of observation. Meanwhile, using a dosage of $10 \mathrm{~mL} / \mathrm{L}$ shows the physical change of the bug's dead body. The fungus appears on the whole bug's dead body. The fungus spreads from day 8 of observation while the dosages of $8 \mathrm{~mL} / \mathrm{L}$ and $10 \mathrm{~mL} /$ $L$ are used. Moreover, the lowest mortality percentage is 28.57\%, while $2 \mathrm{~mL} / \mathrm{L}$ dosages are used for 12 days.
\end{abstract}

Keywords: Beuveria bassiana extract liquid, biological agent, rice ear bug, paddy rice

\begin{abstract}
ABSTRAK
Serangga hama walang sangit merupakan salah satu faktor kegagalan dalam budidaya tanaman padi. Untuk mencegah peningkatan serangan pada tanaman padi, dibutuhkan instektisida alami yang mampu meningkatkan mortalitas walang sangit. Tujuan penelitian ini adalah meningkatkan mortalitas serangga hama walang sangit melalui pemberian agen hayati larutan Beuveria bassiana pada berbagai taraf konsentrasi. Larutan Beuveria bassiana disempotkan pada walang sangit di dalam sungkup jaring pada rumpun tanaman padi. Dosis yang diberikan antara ekstrak beuveria bassiana dengan air menggunakan perbandingan $2 \mathrm{ml} / \mathrm{L}, 5 \mathrm{ml} / \mathrm{L}, 8 \mathrm{ml} / \mathrm{L}$, dan $10 \mathrm{ml} / \mathrm{L}$. Hasil penelitian menunjukkan dosis terbaik untuk pengendalian hama walang sangit pada tanaman padi adalah $10 \mathrm{ml}$ larutan beuveria bassiana per liter air. Hal ini ditunjukkan dari mortalitas walang sangit tertinggi yaitu 76,92 \% selama 12 hari pengamatan. Pada dosis $10 \mathrm{ml} / \mathrm{L}$ telah menunjukkan perubahan fisik pada serangga hama yang telah mati. Cendawan beuveria bassiana muncul di seluruh jaringan tubuh walang sangit yang telah mati. Pertumbuhan cendawan mulai tampak menyelimuti serangga hama yaitu hari ke 8 menggunakan dosis $8 \mathrm{ml} / \mathrm{L}$ air dan $10 \mathrm{ml} / \mathrm{L}$ air. Di samping itu, dosis yang menunjukkan mortalitas terendah pada walang sangit adalah $2 \mathrm{ml} \mathrm{larutan}$ beuveria bassiana per liter air. Mortalitas walang sangit pada dosis ini adalah 28,57 \% selama 12 hari pengamatan.
\end{abstract}

Kata Kunci: agen hayati, larutan Beuveria bassiana, pengendalian hama, serangga hama walang sangit, tanaman padi

\section{PENDAHULUAN}

Tanaman padi merupakan salah satu tanaman yang menghasilkan bahan makanan pokok berupa beras. Pada umumnya, tanaman padi dapat tumbuh di daerah tropis. Iklim di daerah tropis yang hangat mendukung pertumbuhan dan perkembangan beraneka ragam serangga 
pengurai, predator, dan hama bagi tanaman pangan. Hal ini menyebabkan tanaman pangan (padi) yang dibudidayakan manusia, dapat diserang oleh jenis serangga yang merugikan. Dampak serangan ini, mampu menyebabkan terhambatanya pertumbuhan tanaman padi. Selain itu, dampak yang paling berat adalah kegagalan panen.

Salah satu serangga hama yang berpotensi menyebabkan kegagalan panen bagi tanaman padi adalah serangan hama walang sangit (Leptocorisa oratorius F). Serangga hama walang sangit menyerang tanaman padi dengan mengambil sari bulir padi saat tanaman padi memasuki masa generatif. Hal ini menyebabkan tanaman padi memiliki bulir yang kosong sehingga tidak dapat dipanen oleh petani. Saat ini, pengendalian serangga walang sangit dilakukan dengan pembersihan resumputan di sekitar bedengan, dan penyemprotan menggunakan instektisda kimia. Namun, penggunaan penyemprotan instektisida kimia dapat meninggalkan residu di lingkungan sekitarnya (Adriyani, 2006 ; Darmono, 2001). Insektisida kimia dapat mencemari jaringan dan bulir tanaman padi. Selain itu, instektisida kimia dapat mencemari air, tanah, dan udara di sekitarnya. Penggunaan instektida kimia dapat menyebabkan serangga predator yang ada di sekitar tanaman mati. Jika berlanjut terus menerus, hal ini tentu menyebabkan ketidakseimbangan ekosistem yang ada. Untuk itu, dibutuhkan sebuah terobosan yang mampu mencegah pertumbuhan serangga walang sangit pada tanaman padi. Terobosan tersebut berupa pembuatan agen hayati dari larutan beuveria bassiana yang digunakan untuk pengendalian serangga hama walang sangit di tanaman padi. Serangga walang sangit yang telah terpapar cendawan Beuveria bassiana dapat menyebabkan kematian.

Tujuan penelitian ini adalah menguji pengaruh pemberian agen hayati larutan Beuveria bassiana terhadap perubahan tingkat mortalitas serangga hama walang sangit. Pada penelitian ini, dosis larutan Beuveria bassiana merupakan parameter percobaannya. Beberapa penelitian tentang cendawan Beuveria bassiana pernah dilakukan Ondioka et al (2008) yang mengatakan salah satu manfaat aplikasi larutan cendawan Entomopatogen Beauveria bassiana pada tanaman adalah meningkatkan kegagalan penetasan telur serangga hama. Abullah et al (2020) mengatakan aplikasi Beauveria bassiana (Bals.) Vuil. mampu menyebabkan kematian pada nimfa wereng hijau yang menyerang tanaman padi. Aplikasi melalui penyemprotan paling efektif mempengaruhi mortalitas nimfa wereng hijau. Penyemprotan Beauveria bassiana dengan konsentrasi $20 \mathrm{ml} / \mathrm{L}$ air, dapat mencegah hama thrips sp. pada tanaman cabai rawit hingga 99,53 \%. Cendawan Beauveria bassiana tidak berpengaruh terhadap tinggi dan jumlah daun tanaman cabai (Intarti et al., 2020). Penggunaan cendawan Beauveria bassiana tidak menyebabkan kematian pada serangga predator. Beberapa kasus ditemukan yaitu kematian larva dan pupa serangga predator, namun pada fase imago dan dewasa tidak ditemukan kematian akibat penggunaan cendawan Beauveria bassiana sebagai pengendali serangga hama (Tantawizal et al, 2015 ; Sodiq dan Martiningsia, 2009).

Dari penelitian yang dilakukan Tantawizal et al (2015) Penggunaan pada cendawan Beauveria Bassiana untuk pengendalian serangga hama, tidak berpengaruh terhadap populasi predator Oxyopes sp., Lycosa sp., dan Paederus sp. Rosmiati et al (2018) mengatakan beauveria bassiana dapat digunakan seagai pengendali hama hayati (alami) karena efektif mengendalikan popolasi serangga hama pada tingkat mortalitas $82,5 \%$. Ikawati (2016) mengatakan cendawan Beauveria bassiana aman pada manusia. Jamur Beauveria bassiana mampu mengendalikan populasi nyamuk genus Culex, Aedes dan Anopheles. Mekanisme serangan cendawan beauveria bassiana pada nyamuk yaitu spora atau inokulum cendawan masuk pada serangga inang melalui kulit, saluran pencernaan, spirakel, ataupun lubang lainnya pada tubuh nyamuk. Cendawan mengeluarkan racun Beauverin yang membuat kerusakan tubuh serangga. Wahyudi (2008) mengatakan bahwa jamur Beauveria bassiana dapat dipadatkan sehingga dapat disimpan. Enkapsulasi jamur Beauveria bassiana membuat jamur dapat bertahan dan efektif saat digunakan kemudian hari. Hasil peneltian ini membuka implementasi teknologi yang mampu mencampur dan menyemprotkan larutan Beauveria bassiana secara 
berkesinambungan dalam jangka waktu yang panjang.

\section{BAHAN DAN METODE}

Kegiatan penelitian ini telah dilaksanakan kebun percobaan Dinas Pertanian Gading Rejo, Pringsewu, Lampung. Alat yang digunakan dalam penelitian ini untuk pembuatan larutan Beuveria bassiana adalah autoclafe, panci dan kompor gas, stopwatch, dan kawat nikrom. Bahan yang dibutuhkan membuat larutan beuveria bassiana dalam penelitian ini adalah air cucian beras, cendawan Beuveria bassiana dalam bentuk PSA, dan alkohol. Larutan cendawan Beuveria bassiana yang telah dibuat, disemprotkan dengan menggunakan sprayer untuk mengendalikan populasi serangga hama walang sangit pada tanaman padi.

\subsection{Prosedur Pelaksanaan}

Objek penelitian ini adalah serangga walang sangit yang ditemukan pada budidaya tanaman padi, khususnya pada masa tanaman padi telah memiliki bulir padi jenis ciherang (Gambar 1). Penelitian ini diawali dengan menangkap serangga walang sangit di lahan pertanian padi. Dari hasil pengamatan di lokasi penelitian, ditemukan banyak walang sangit, sehingga menggangu pertumbuhan bulir tanaman padi. Penangkapan walang sangit menggunakan galah sepanjang 2 meter yang memiliki jaring di ujungnya (Gambar 2). Penangkapan ini dilakukan pada pagi hari di lahan sawah. Serangga walang sangit yang telah berhasil ditangkap, kemudian dimasukkan ke dalam wadah yang memiliki aerasi pada kategori baik.
Sampel tanaman padi sebanyak 5 rumpun dipindahkan pada umur 35 HST secara acak dari lahan percobaan. Rumpun tanaman padi dipindahkan bersama dengan akar tanaman ke dalam ember agar tetap dapat bertumbuh saat pelaksanaan penelitian. Tanaman padi yang telah diambil, digunakan untuk media pertumbuhan walang sangit selama percobaan (Gambar 3). Tanaman padi yang telah dipindahkan ke dalam ember diberi sungkup jaring nilon. Sungkup jaring ini berfungsi untuk mencegah serangga walang sangit lolos dari pengamatan saat terkena paparan cendawan Beuveria bassiana.

Untuk menyangga sungkup nilon dan tanaman padi secara kokoh, 3 batang ajir (tiang penyangga) diletakkan di sekitar tanaman padi. Serangga walang sangit yang telah diperoleh, dimasukkan ke dalam sungkup yang berisi tanaman padi. Diameter ember plastik yang digunakan adalah $35 \mathrm{~cm}$. Banyak anakan tanaman padi yang dipindahkan berkisar antara 30-38 batang dan rata-rata tinggi tanaman padi pada kisaran $56-60 \mathrm{~cm}$. Jumlah serangga hama walang sangit yang dimasukkan ke dalam sungkup tanaman padi berjumlah 45 ekor (Tabel 1). Populasi serangga walang sangit divariasikan agar sebaran infeksi jamur yang terpapar serangga sesuai dengan implementasi di lahan dan tampak natural.

Pada penelitian ini, pot A1 sebagai populasi walang sangit tanpa perlakuan penyemprotan larutan Beauveria bassiana. Pot A2 adalah populasi walang sangit dengan penyemprotan 2 $\mathrm{ml} / \mathrm{L}$ air, Pot A3 adalah populasi walang sangit menggunakan konsentrasi penyemprotan $5 \mathrm{ml} /$

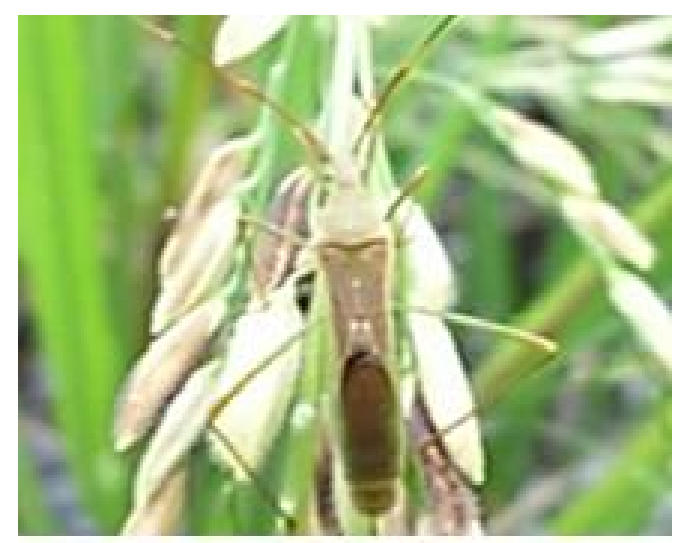

Gambar 1. Walang Sangit (Purwaningsih et al, 2018) 


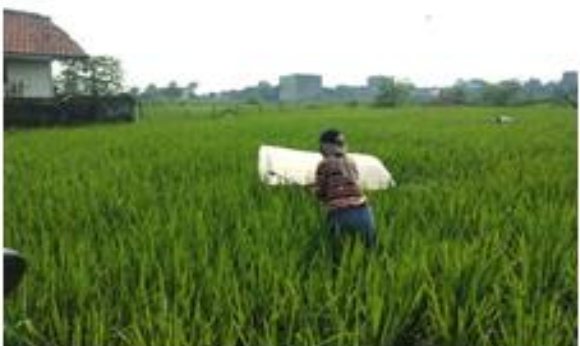

a

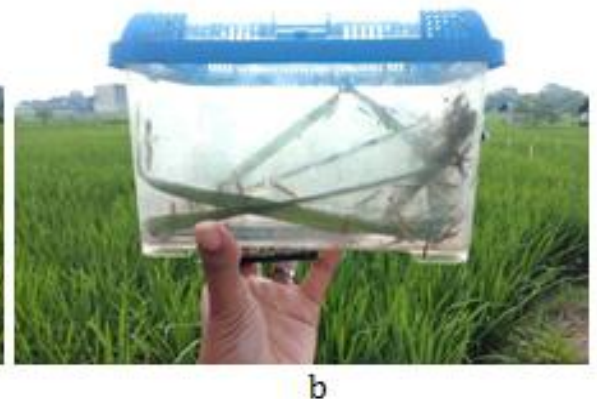

Gambar 2. (a) Proses Penangkapan Serangga Walang Sangit dan (b) Hasil Tangkapan Walang Sangit

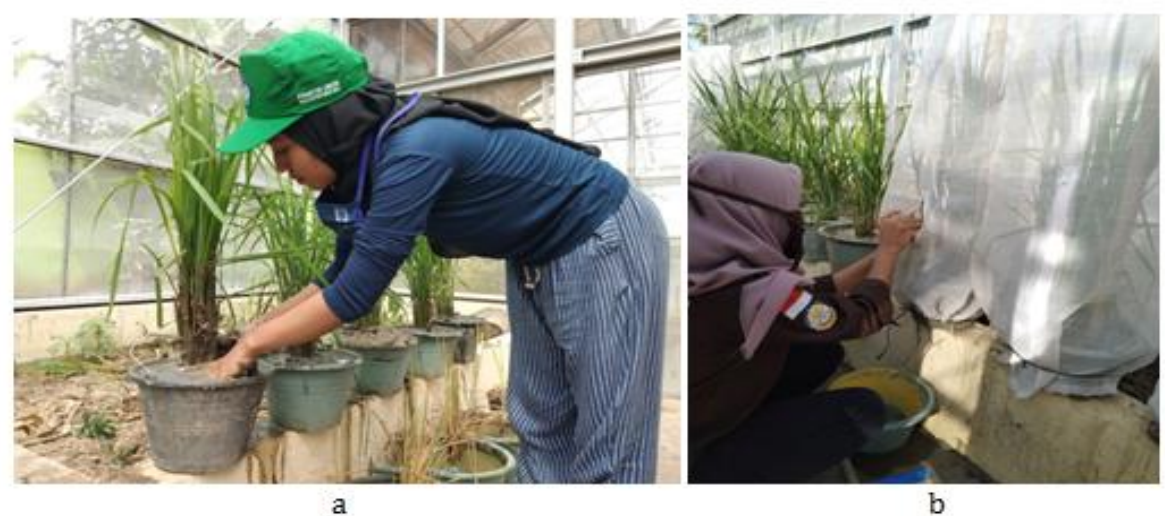

Gambar 3. (a) Sampel Pot Tanaman A1-A5 dan (b) Pembuatan Jaring Nilon untuk Mengurung Walang Sangit

Tabel 1. Populasi Walang Sangit, Jumlah Anakan, dan Tinggi Tanaman pada 35 HST di Media Ember

\begin{tabular}{cccc}
\hline Sampel & $\begin{array}{c}\text { Kepadatan } \\
\text { Serangga (ekor) }\end{array}$ & $\begin{array}{c}\text { Banyak Anakan } \\
\text { Tanamn Padi }\end{array}$ & Tinggi Tanaman (cm) \\
\hline A1 & 5 & 32 & 56 \\
A2 & 7 & 36 & 60 \\
A3 & 9 & 36 & 57 \\
A4 & 11 & 38 & 58 \\
A5 & 13 & 30 & 56 \\
\hline
\end{tabular}

$\mathrm{L}$ air, pot A4 adalah populasi walang sangit dengan penyemprotan $8 \mathrm{ml} / \mathrm{L}$ air, dan pot A5 adalah populasi walang sangit dengan penyemprotan $10 \mathrm{ml} / \mathrm{L}$ air (Gambar 3).

\subsection{Proses Pembuatan Larutan Beauveria Bassiana}

Serangga walang sangit yang telah ditumbuhi cendawan Beauveria bassiana, dapat dimanfaakan kembali menjadi bahan untuk tujuan perbanyakan. Spora cendawan tersebut diletakkan pada media potato sukrose agar (PSA) atau potato dextrose agar (PDX) agar dapat berkembang dengan baik. Octavia dan Wantini (2017) mengatakan komposisi Potato sukrose agar adalah semisintetik karena tersusun dari kentang, sintetik dextrose, dan agar. Karbohidrat, vitamin, dan mikronutrien yang dikandung oleh kentang sebagai bahan makanan untuk pertumbuhan cendawan. Dextrose adalah karbohidrat sederhana sebagai sumber energi dan agar-agar sebagai bahan pemadat campuran bahan lainnya. Perbanyakan cendawan dilanjutkan dengan memanfaatkan media beras yang menjadi agensi hayati tanaman. Melalui bantuan media beras, muncul spora Beauveria bassiana yang diperbanyak kembali, hingga diperoleh spora yang murni. Spora yang murni ini yang digunakan untuk pembuatan larutan untuk menekan pertumbuhan serangga walang 
sangit pada tanaman padi.

\subsection{Proses Perbanyakan Larutan Beauveria bassiana}

Pembuatan larutan Beauveria bassiana terdiri dari dua tahap, yaitu pembuatan bakal bakal Beauveria bassiana (F1) dan perbanyakan cendawan Beauveria bassiana (F1). Pembuatan bakal cendawan Beauveria bassiana diawali dengan mengambil bakal cendawan yang ada pada walang sangit yang telah mati terkena jamur Beauveria bassiana. Selain itu, bakal cendawan Beauveria bassiana dapat diperoleh di pusat laboratorium pertanian di setiap provinsi di Indonesia. Air rebusan kentang yang telah berwarna putih keruh, dicampur media agar-agar sebagai media pertumbuhan bakal cendawan. Media ini ditempatkan dalam tabung reaksi. Selanjutnya, bakal cendawan dimasukkan ke tabung reaksi bersama dengan media pertumbuhan yang telah disiapkan sebelumnya. Tabung reaksi ditutup dan diletakkan pada kondisi intensitas cahaya dan suhu kamar. Perkembangan bakal jamur ini disebut turunan F0.

Langkah berikutnya adalah perbanyakan cendawan Beauveria bassiana. Pengerjaannya perbanyakan cendawan Beauveria bassiana dalam kondisi steril, untuk mendukung pertumbuhannya. Penyemprotan seluruh peralatan dilakukan menggunakan alkohol. Selanjutnya, perendaman beras dengan air dilakukan selama beberapa jam. Air rendaman yang layak digunakan adalah air yang telah tampak putih keruh. Beras yang telah ditiriskan, dimasukkan ke dalam plastik bening. Beras dimasukkan ke dalam autoclafe pada suhu 121 oC selama 15-20 menit dengan mengeluarkan udara bertekanan secara bertahap pad 5 menit pertama.

Perlakuan meremahkan beras tetap dilakukan di atas panci panas, untuk menghindari kontaminasi jamur atau bakteri lain dari udara sekitaranya. Panci yang panas digunakan untuk menjamin kebersihan udara di atas panci panas, sehingga bakteri atau jamur yang bertebaran di udara dapat terkendali. Cendawan dalam bentuk butiran dimasukkan ke dalam remahan beras. Dosis yang dimasukkan ke dalam beras, mempengaruhi kecepatan tingkat pertumbuhan cendawan. Beras dan cendawan yang telah tercampur diikat hingga udara tidak dapat masuk. Perbanyakan jamur ini disebut turunan F1. Media tersebut disimpan di dalam nampan selama 1-2 minggu, sebelum dapat disemprotkan pada tanaman padi.

\subsection{Parameter}

Parameter pengamatan pada penelitian ini adalah dampak pemberian larutan Beuveria bassiana terhadap mortalitas dan pertumbuhan cendawan pada walang sangit. Mortalitas serangga hama walang sangit diamati pada hari ke 1 hingga hari ke 12 setelah aplikasi larutan Beuveria bassiana. Umumnya, serangan jamur Beuveria bassiana mulai tampak pada hari 5, 6, 8, 10 saat jamur telah menginfeksi dan menyebabkan kematian pada serangga, sedangkan hari ke 10,12, 14 dan seterusnya adalah fase pertumbuhnya cendawan pada tubuh serangga yang telah mati. Perlakuan larutan beuveria bassiana menggunakan dosis $2 \mathrm{ml} / \mathrm{L}$ air, $5 \mathrm{ml} / \mathrm{L}$ air, $8 \mathrm{ml} / \mathrm{L}$ air, dan $10 \mathrm{ml} / \mathrm{L}$ air yang di semportkan pada walang sangit yang berada di sekitar tanaman padi. Persentase mortalitas serangga walang sangit dihitung menggunakan persamaan :

$$
\mathrm{P}=\frac{a}{a+b} \times 100 \%
$$

Dimana, $\mathrm{P}$ adalah persentase mortalitas walang sangit, a adalah jumlah walang sangit mati pada setiap perlakuan, dan $\mathrm{b}$ adalah jumlah walang sangit hidup pada setiap perlakuan.

\section{HASIL DAN PEMBAHASAN}

Pestisida organik dan agen hayati merupakan larutan yang dapat mengendalikan serangga hama, jamur, dan bakteri yang menyerang tanaman. Perbedaan pestisida dan agen hayati berasal dari bahan pembuatannya. Pestisida organik berasal dari tanaman yang diekstrak. Hasil ekstrak tanaman tersebut mengandung bahan (unsur) kimia yang tidak disukai (racun) bagi perkembangan serangga hama, jamur, bakteri dan virus. Agen hayati berasal dari mahluk hidup seperti bakteri ataupun jamur yang diperbanyak (diproduksi) untuk mengendalikan populasi serangga hama, bakteri, jamur, dan virus yang menyerang tanaman. 
Beauveria bassiana merupakan jamur yang dapat sistem motorik serangga hama walang sangit. Cara kerja agen hayati Beauveria bassiana yaitu dengan pertumbuhan jamur yang menembus katikula (cangkang/kulit) serangga walang sangit. Hifa jamur yang menembus kaltikula jamur, menyebabkan reaksi berantai pada sistem saraf serangga walang sangit. Hifa Beauveria bassiana bertumbuh dengan memanfaatkan jaringan tubuh walang sangit sebagai inangnya. Pertumbuhan hifa Beauveria bassiana yang massif menyebabkan serangga mati.

Penyemprotan larutan Beauveria bassiana telah berhasil meningkatkan mortalitas serangga hama. Serangga hama walang sangit mengalami penurunan jumlah akibat pertumbuhan cendawan yang mengganggu jaringan tubuhnya (Tabel 2). Dari hasil pengamatan, didapatkan hasil bahwa mortalitas tertinggi pada perlakuan $10 \mathrm{ml} / \mathrm{L}$ air pada hari ke 12. Penggunaan konsentrasi $10 \mathrm{ml}$ larutan/L air, telah menunjukkan kematian pada walang sangit pada hari ke 5. Tingkat mortalitas yang didapat adalah $30,769 \%$. Pada konsentrasi $10 \mathrm{ml}$ larutan/liter air tingkat mortalitas tertinggi yang didapatkan pada hari ke 12 yaitu 76,923 \%. Mortalitas terendah ditunjukkan pada perlakuan $2,0 \mathrm{ml}$ larutan Beauveria bassiana per liter air. Penggunaan konsentrasi 2,0 ml larutan Beauveria bassiana per liter air, telah menunjukkan kematian pada walang sangit pada hari ke 8. Tingkat mortalitas yang didapat adalah $14,286 \%$. Pada konsentrasi 2 ml larutan beauveria bassiana per liter air tingkat mortalitas tertinggi yang didapatkan pada hari ke 12 yaitu 28,571 \%. Hal ini menunjukkan bahwa konsentrasi larutan Beauveria bassiana mempengaruhi durasi efektivitas dan tingkat mortalitas pada serangga walang sangit yang terpapar. Perhitungan mortalitas dapat dihitung menggunakan Persamaan 1.

Pada penelitian ini, infeksi cendawan Beuveria bassiana pada serangga hama terjadi karena terjadinya kontak konidiospora secara langsung ataupun secara pasif seperti bantuan angin, semprotan langsung, atapun saat serangga hama bersinggungan (bersentuhan). Menurut Boucias dan Pendland (1998) cara kerja spora Beuveria bassiana yang telah terpapar pada seranga walang sangit berbentuk tabung kecambang, yang menembus integumen secara mekanis dan kimia pada jaringan tubuh serangga. Proses ini dilakukan dengan menggunakan enzim-enzim yang mampu menguraikan komponen penyusun kutikula serangga walang sangit (Semangun et al., 1994). Pertumbuhan cendawan pada tersebut menyebabkan serangga walang sangit menjadi lambat, perilaku yang tidak tenang, kejang, ganggungan motorik, kegagalan pernapasan, dan menyebabkan kematian. Jamur yang telah berkembang pada jaringan tubuh serangga membentuk kandiospora (Tanada dan Kaya, 1993). Jamur yang telah berkembang pada jaringan tubuh serangga hama, dapat ekstrak dan dikembangkan untuk perbanyakan cendawan Beuveria bassiana kembali.

Pada Gambar 4 menunjukkan bahwa, mortalitas serangga hama walang sangit meningkat setiap hari. Perubahan komposisi 10 ml larutan Beauveria bassiana per liter air menunjukkan perubahan kematian walang sangit dari hari ke 5 hari setetelah aplikasi (HSA) sejumlah 3 ekor hingga pada hari 12 yaitu 10 ekor. Hasil analisis menggunakan metode program linear menghasilkan model matematika penurunan populasi serangga hama walang sangit pada tanaman padi menggunakan konsentrasi $10 \mathrm{ml} /$ L air adalah $y=1,0105 x-2,3182$ dengan koefisien

Tabel 2. Mortalitas Serangga Walang Sangit Akibat Cendawan Beauveria Bassiana

\begin{tabular}{ccccc}
\hline $\begin{array}{c}\text { Perlakuan } \\
\text { (ml/liter Air) }\end{array}$ & \multicolumn{4}{c}{ Rerata Mortalitas Walang Sangit (\%) Hari Setelah Aplikasi (HSA) } \\
\cline { 2 - 5 } 6 hari & $\mathbf{8}$ hari & 10 hari & 12 hari \\
\hline 2,0 & 0,000 & 14,286 & 14,286 & 28,571 \\
5,0 & 11,111 & 22,222 & 33,333 & 44,444 \\
8,0 & 18,182 & 36,364 & 45,455 & 63,636 \\
10,0 & 30,769 & 38,462 & 61,538 & 76,923 \\
\hline Kontrol & 0 & 0 & 0 & 0 \\
\hline
\end{tabular}

Keterangan: (A1) control ; (A2) 2,0 ml ; (A3) 5,0 ml ; (A4) 8,0 ml ; (A5) 10,0 ml 
determinasi 0,9591. Komposisi 2 ml larutan beauveria bassiana per liter air menunjukkan perubahan kematian walang sangit yang lebih lambat yang dimulai pada dari hari ke 8 sejumlah 1 ekor hingga pada hari 12 yaitu 2 ekor. Sifat cendawan yang telah disemprot pada walang sangit, dapat menyerang serangga hama walang sangit berkelanjutan.

Larutan yang mengandung cendawan Beuveria bassiana merupakan salah satu patogen ramah lingkungan, karena tidak menghasilkan residu yang berbahaya dan tidak menimbulkan resistansi hama. Cendawan Beuveria bassiana muncul setelah serangga hama walang sangit mati berbentuk spora. Ciri-ciri spora yang muncul di seluruh bagian tubuh walang sangit adalah ditemukannya hifa berwarna putih, bersekat, dan bulat lonjong. Kemunculan spora hampir merata pada tubuh walang sangit. Spora Beuveria bassiana menutupi jaringan tubuh serangga walang sangit (Gambar 5).

Proses perkembangan jamur menjadi spora terjadi saat walang sangit telah mati. Perkembangan spora dapat diamati dengan munculnya bintik bintik putih pada bagian

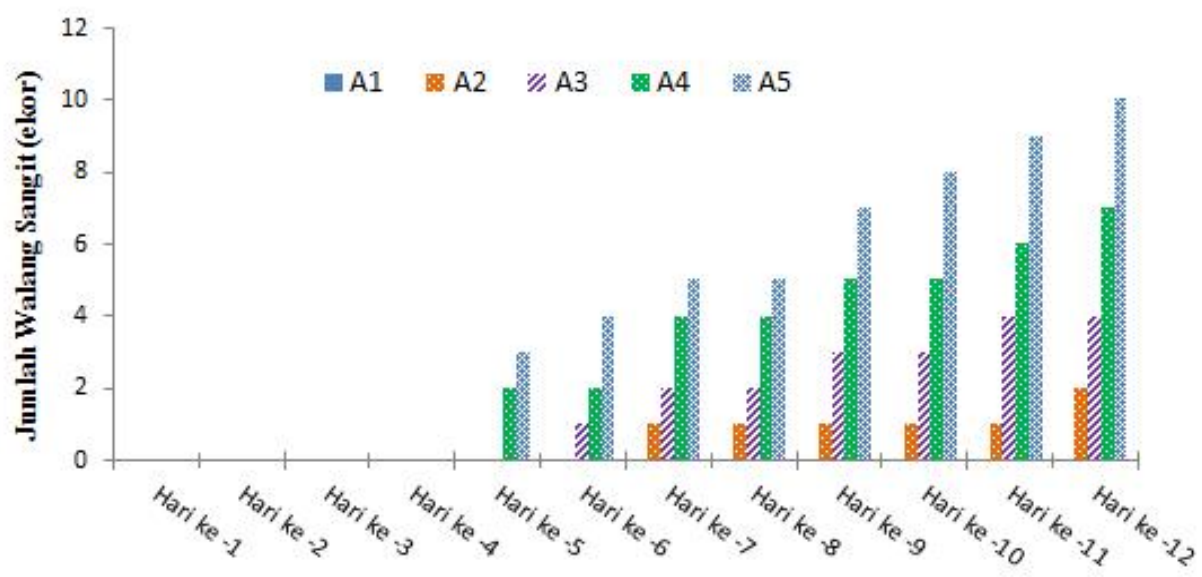

Gambar 4. Peningkatan Kematian Walang Sangit dalam 12 HSA

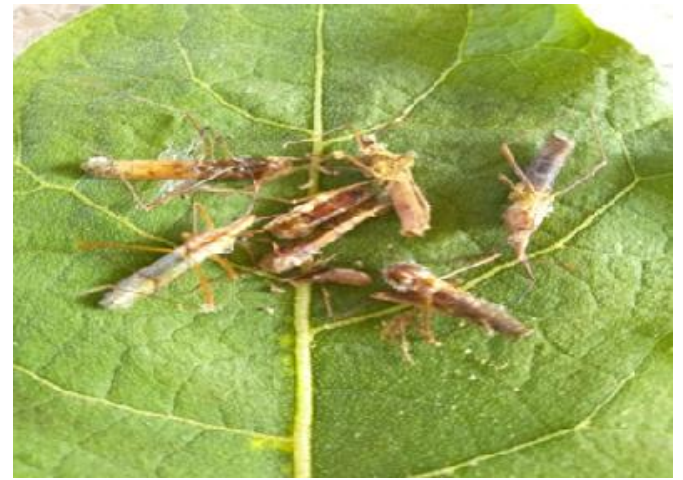

Gambar 5. Kemunculan Cendawan Beauveria Bassiana (Berwarna Putih) pada Walang Sangit

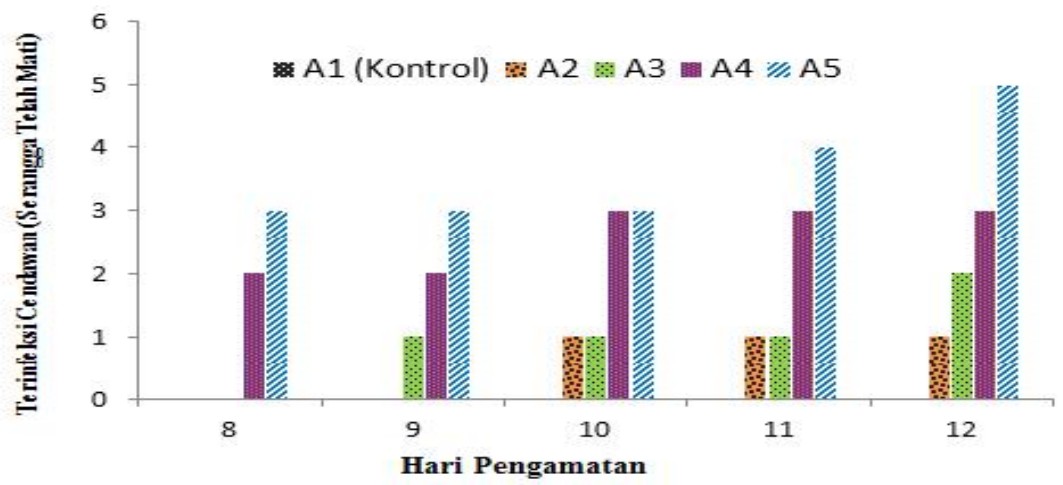

Gambar 6. Serangga Walang Sangit Teridentifikasi Pertumbuhan Cendawan 
Tabel 3. Model Matematika Serangga Mati dan Pertumbuhan Cendawan

\begin{tabular}{|c|c|c|c|c|}
\hline \multirow{2}{*}{ Jenis Perlakuan } & \multicolumn{2}{|c|}{ Serangga yang mati (y) } & \multicolumn{2}{|c|}{ Kemunculan Cendawan (y) } \\
\hline & Model Matematika & $\mathbf{R}^{2}$ & Model Matematika & $\mathbf{R}^{2}$ \\
\hline Kontı & Tidak ada serangga mati & & Tidak ada pertumbu & dawan \\
\hline $2 \mathrm{ml}(\mathrm{A} 2)$ & $y=0,1643 x-0,4848$ & 0,785 & $y=0,3 x-0,3$ & 0,75 \\
\hline $5 \mathrm{ml}(\mathrm{A} 3)$ & $y=0,4301 x-1,2121$ & 0,914 & $y=0,4 x-0,2$ & 0,8 \\
\hline $8 \mathrm{ml}(\mathrm{A} 4)$ & $y=0,6958 x-1,6061$ & 0,949 & $\mathrm{y}=1,7709 \mathrm{e}^{0,1216 \mathrm{x}}$ & 0,79 \\
\hline $10 \mathrm{ml}$ (A5) & $y=1,0105 x-2,3182$ & 0,959 & $y=2,3762 e^{0,1309 x}$ & 0,793 \\
\hline
\end{tabular}

Keterangan : $\mathrm{x}=$ Hari setelah aplikasi (HSA)

tubuh walang sangit. Dari hasil pengamatan, didapatkan kondisi cendawan muncul pada hari ke 9 setelah aplikasi (HSA). Dari hasil pengamatan, tidak ditemukan kematian walang sangit pada perlakuan kontrol. Hal ini menunjukkan bahwa serangga walang sangit tidak terpapar jamur dan dapat hidup selama 12 hari pada tanaman padi di dalam jaring. Perlakuan A2 (2 ml/L air), A3 (5 ml/L air), A4 (8 ml/L air) dan A5 (10 ml/L air) menunjukkan kemunculan spora pada hari ke 9 hsa. Rasio tertinggi kemunculan spora terhadap kematian serangga walang sangit yaitu pada perlakuan A3 yaitu $60 \%$ pada hari ke 10 . Namun, pertumbuhan spora tertinggi pada perlakuan A5 yaitu 5 ekor pada hari ke 12 (Gambar 6). Laju pertumbuhan cendawan pada serangga walang sangit yang telah mati pada dosis $10 \mathrm{ml} / \mathrm{L}$ air adalah $\mathrm{y}=$ $2,3762 \mathrm{e}^{0,1309 \mathrm{x}}$ dengan koefisien determinasi 0,793 . Model matematika antara walang sangit yang mati dan kemunculan cendawan dengan dosis penyemprotan dapat dilihat pada Tabel 3 .

Cendawan Beauveria bassiana memiliki keunggulan yaitu tidak menyebabkan kematian pada serangga predator yang ada di sekitar tanaman, tidak menyebabkan pencemaran lingkungan yang meninggalkan residu bagi produk pertanian, penggunaan membutuhkan biaya yang terjangkau, dan aman bagi manusia (Intarti et al, 2020 ; Abdullah et al, 2020 ; Tantawizal et al, 2015 ; Sodiq dan Martiningsia, 2009 ; Ikawati, 2016). Hasil penelitian ini akan digunakan sebagai dasar penggunaan pestisida dari agen hayati yang terintegrasi dengan pemikat otomatis, perangkap otomatis dan penyemrot pestisida otomatis (Telaumbanua et al, 2020). Integrasi penggunaan pestisida dari larutan Beuveria bassiana dengan penyemprot otomatis dapat mendukung pengembangan organic precission farming di Indonesia.

\section{KESIMPULAN}

Pada penelitian ini, agensi hayati Beauveria bassiana mampu menghambat perkembangan serangga hama walang sangit. Serangga hama walang sangit yang telah terpapar agensi hayati akan mati perlahan yang ditandai dengan pertumbuhan hifa cendawan Beauveria bassiana pada jaringan tubuhnya. Dari hasil pengamatan, laju penurunan populasi serangga hama walang sangit pada tanaman padi menggunakan konsentrasi $10 \mathrm{ml} / \mathrm{L}$ air adalah y $=1,0105 \mathrm{x}-2,3182$ dengan koefisien determinasi 0,9591 . Tingkat mortalitas tertinggi yaitu 76,92 $\%$ pada serangga hama walang sangit yang diperoleh dari dosis $10 \mathrm{ml}$ Beauveria bassiana per liter air. Kematian serangga hama walang sangit tercepat terjadi pada hari ke 5 setelah aplikasi (HAS) pada dosis $10 \mathrm{ml} / \mathrm{L}$ air. Tingkat mortalitas terendah yaitu $28,57 \%$ yang diperoleh dari dosis $2 \mathrm{ml} / \mathrm{L}$ air. Pertumbuhan cendawan mulai tampak menyelimuti serangga hama yaitu pada hari ke 8 dosis $8 \mathrm{ml} / \mathrm{L}$ air dan $10 \mathrm{ml} / \mathrm{L}$ air. Laju pertumbuhan cendawan pada serangga walang sangit yang telah mati pada dosisi $10 \mathrm{ml} /$ $\mathrm{L}$ air adalah $\mathrm{y}=2,3762 \mathrm{e}^{0,1309 \mathrm{x}}$ dengan koefisien determinasi 0,793 . Semakin tinggi dosis yang diberikan, maka tingkat mortalitas serangga hama walang sangit semakin tinggi dan kematian serangga hama walang sangit semakin cepat.

\section{DAFTAR PUSTAKA}

Abdullah, T., Kuswinanti, T., Nurariaty, A., Daud, I, D., Nasruddin, A., Risal, R., Utami, S., and Tuwo, M. 2020. Application of Beauveria bassiana (Bals.) Vuil. (Hypocreales: Cordycipitaceae) in rice seed and its effect on mortality of green leaf hopper, Nephotettix virescens (Distant) 
(Homoptera: Cicadellidae). IOP Conf. Series: Earth and Environmental Science 486. doi:10.1088/1755-1315/486/1/ 012150.

Adriyani, R. 2006. Usaha Pengendalian Pencemaran Lingkungan Akibat Penggunaan Pestisida Pertanian. Usaha Pengendalian Pencemaran Lingkungan 3:95-106.

Boucias, D. G. and Pendland, J. C. 1998. Principles of Insect Pathology. London: Kluwer Academic Publishers. 102p

Darmono. 2001. Lingkungan Hidup dan Pencemaran : Hubungannya dengan Toksikologi Senyawa Logam. Jakarta : Penerbit Universitas Indonesia.

Ikawati, B. 2016. Beauveria Bassiana as alternative for Mosquito Biological Control. Jurnal Vektor Penyakit 10 (1): 19-24

Intarti, D, Y., Kurniasari, I., Sudjianto, A. 2020. The Effectivity of Biocontrol Agent Beauveria bassiana Against Thrips sp. on Chili Pepper (Capcisum frutescens L.). Agrovigor 13(1):10-15.

Octavia, A., dan Wantini, S. 2017. Perbandingan pertumbuhan cendawan Aspergillus Flavus pada Media PDA (Potato Dextrose Agar) dan Media Alternative dari singkong (Manihot esculenta Crantz). Jurnal Analis Kesehatan 6 (1) : 625-631.

Ondioka, S., N. Maniania, G. Nyamasya, and J.N. deritu. 2008. Virulence of the entomopathogenic fungus Beauveria bassiana and Metarhizium anisopliae to Sweet Potato Weevil Cylas Formicarius and Effects on Fecundity and Egg viability. Ann of Appl. Biol. 153: 4148.

Purwaningsih T., Kristanto B.A., Karno. 2018. Efektifitas Aplikasi Beauveria bassiana
Sebagai Upaya Pengendalian Wereng Batang Coklat dan Walang Sangit pada Tanaman Padi di Desa Campursari Kecamatan Bulu Kabupaten Temanggung. J. Agro Complex 2(1):12-18.

Rosmiati, A., Hidayat, C., Firmansyah, E dan Setiati, Y. 2018. Potensi Beauveria Bassiana Sebagai Agens Hayati Spodoptera litura Fabr. pada Tanaman Kedelai. Jurnal Agrikultura 29 (1): 43-47.

Semangun, H., 1994. Penyakit - Penyakit Tanaman Hortikultura di Indonesia. Gadjah Mada University Press. Yogyakarta.

Sodiq, M., and Martiningsia, D. 2009. Pengaruh Beauveria Bassiana Terhadap Mortalitas Semut Rangrang Oecophlia smaragdina (F) (Hymenoptera : Formicidae). J. Entomol 6 (2);53-59.

Tanada, Y., and H.K. Kaya, 1993. Insect Pathology. Academic Press, Inc., New York, NY. p 666.

Tantawizal., Inayati, A., dan Prayogo, Y. 2015. Potensi Cendawan Entomopatogen Beauveria Bassiana (Balsamo) Vuillemin Untuk Mengendalikan Hama Boleng Cylas Formicarius F. Pada Tanaman Ubijalar. Buletin Palawija 29: 46-53.

Telaumbanua, M., Haryanto, A., Wisnu, F, K., Lanya, B., Wiratama, W. 2020. Design of Insect Trap Automatic Control System for Cacao Plants. Procedia Environmental Science, Engineering and Management (Accepted).

Wahyudi, P. 2008. Enkapsulasi Propagul Jamur Entomopatogen Beauveria Bassiana Menggunakan Alginat dan Pati Jagung Sebagai Produk Mikoinsektisida. Jurnal Ilmu Kefarmasian Indonesia 6(2):51-56. 